FACTA UNIVERSITATIS

Series: Philosophy, Sociology, Psychology and History Vol. 19, No 3, 2020, pp. 241 - 255

https://doi.org/10.22190/FUPSPH2003241T

Original Scientific Paper

\title{
JUDGING THE ONLINE JUDGES: THE TWO \#METOO CASES IN HONG KONG
}

UDC 343.541-055.2:004.738.5(512.317)

\section{Chris Y. H. Tsui}

School of Media, Communication and Sociology, University of Leicester, UK

\begin{abstract}
On November 30, 2017, Hong Kong track athlete Vera Lui posted a photo on Facebook marked with the \#MeToo hashtag and described an experience of being sexually assaulted. Three days later, Hong Kong actress Louisa Mak published a similar \#MeToo post on her Facebook page. While both posts, especially Lui's, initially received many supportive comments, over time, the comments became negative and victimblaming. Since these incidents, no other Hong Kong celebrities have risked revealing their experiences to respond to the \#MeToo Movement. In this paper, I analysed the first 500 comments posted on each of the posts using qualitative content analysis and critical discourse analysis. The results reveal the practice of online judging that inhibits the disclosure of cases of sexual assault. The paper further describes the interplay between online judging and selective law enforcement by the Hong Kong Police, which has been a persistent issue in Hong Kong.
\end{abstract}

Key words: \#MeToo, Hong Kong, online judging, rape culture, secondary victimization, selective law enforcement.

\section{INTRODUCTION}

On November 30, 2017, her $23^{\text {rd }}$ birthday, Hong Kong track athlete Vera Lui posted a photo on her Facebook page which showed her holding a paper with the \#MeToo hashtag written on it. ${ }^{1}$ In the description of the photo, she described her experience of being sexually assaulted when she was about 13 years old - her previous athletics coach escorted her home on the pretext of giving her a massage, and subsequently sexually assaulted her. Before posting this, she had only told one of her best friends about this incident. In the summer of 2017, she read the news about Taiwanese writer Yi-han Lin, who committed

Received August 25, 2020 / Accepted November 24, 2020

Corresponding author: Chris Tsui

The University of Leicester, University Road, Leicester, LE1 7RH, United Kingdom

E-mail: yht3@leicester.ac.uk

${ }^{1}$ Different people may have used different hashtags, such as \#MeToo, \#Metoo, or \#metoo, but the differences do not alter their meanings. For the sake of consistency, "\#MeToo" is used in this paper. 
suicide after publishing a novel which seemingly depicts her own experience of being sexually assaulted (Chen, Liu, and Cheng 2017). At that time, however, Lui was not brave enough to reveal her story. Inspired by American gymnast McKayla Maroney, ${ }^{2}$ Lui plucked up the courage to share her ordeal by posting the photo. Through this post, Lui wished to raise public awareness of sexual assaults against children. She noted that sex is not a forbidden topic of conversation in Hong Kong, and hoped that victims of sexual assault would take courage to seek help from their relatives and friends.

Three days after Lui's post, Hong Kong actress Louisa Mak posted a similar photo on her Facebook page. She claimed that she had been sexually assaulted on numerous occasions in mainland China. Given her experiences and her fundamental knowledge of the law, Mak used Lui's case as an example to demonstrate how victims can increase their probabilities of winning court trials. Mak encouraged those women who have suffered sexual assault to take legal actions against the perpetrators. Lui's Facebook post received thousands of comments, and Mak's received hundreds, suggesting the likelihood of the \#MeToo Movement gaining prominence in Hong Kong. Before discussing the development of the \#MeToo Movement in Hong Kong, I will briefly introduce the \#MeToo Movement in the following section.

\section{THE \#METOO MOVEMENT: AN INTRODUCTION}

In 2006, a 13-year-old girl confided in African-American social activist, Tarana Burke, about her experience of being sexually assaulted. Having failed to provide the girl with an immediate response, Burke later created a documentary titled Me Too to address the issues raised by the girl. Through her documentary, Burke wished to empower the victims of sexual assault, especially women of colour, by empathising with their situations, and wanted them to appreciate that they were not alone in facing the aftermath of such incidents (Boyle 2019, 4-5; Ohlheiser 2017; Pellegrini 2018, 262; Rodino-Colocino 2018, 97).

On October 15, 2017, American actress Alyssa Milano posted a tweet to encourage all victims of sexual harassment and assault to speak up by spreading the hashtag \#MeToo over the Internet. Through this movement, she aimed to raise public awareness of the seriousness of sexual harassment and assault around the world (Boyle 2019, 3; Mendes, Ringrose, and Keller 2018, 236). Within the first 24 hours of Milano's tweet, millions of women responded by sharing their stories on various social media platforms using the \#MeToo hashtag (Gentile 2018, 258; Kunst et al. 2019, 818). To date, this movement has spread to over 80 countries worldwide (Gill and Orgad 2018, 1317), including China, where Twitter, Facebook, and Instagram - prominent social media platforms of the movement - are banned.

In light of the censorship and surveillance around the "Great Firewall of China" (Healy 2007, 158), the participation of Chinese netizens in the \#MeToo Movement was limited via access to online platforms developed in China, such as Weibo and WeChat. For example, a computer scientist, Xixi Luo, wrote an open letter on Weibo in January 2018, stating that her former supervisor, Xiaowu Chen, had attempted to sexually assault her during her doctoral studies (Denyer and Wang 2018). In response to posts that were similar to Luo's, the China Daily, one of the state-owned newspapers, declared that cases of sexual harassment and assault were infrequent in China given the robust education and rich culture that had instilled in its people deep respect for women (Hassan 2017). However,

\footnotetext{
2 Maroney posted a tweet to accuse the team doctor, Larry Nassar, of repeatedly sexually abusing her (@McKaylaMaroney, October 18, 2017).
} 
in order to revive the debate, some netizens highlighted an article published by Srivastava and $\mathrm{Gu}$ (2009), which notes that 80 per cent of Chinese working women have experienced sexual misconduct in the workplace to some extent. The readers' reactions to this article were twofold: some thought that the paper was defaming the Chinese society, while others searched the Internet for more information about sex crimes in China. The latter reaction resulted in the Chinese authorities blocking hashtags such as \#MeToo and \#WoYeShi from the Internet domestically. ${ }^{3}$ Therefore, Chinese search engines do not display any results when netizens search for these censored hashtags (Hernández and Mou 2018, A10).

From the Chinese authorities' denials of widespread sexual violence, we can imagine that rape culture is prevalent in Chinese society (Fadnis 2018, 1750-1751; Mendes 2015, 5). Rape culture is a socio-cultural context in which sexual violence is fostered and encouraged through "teaching males and females that it is natural and normal for sexual relations to involve aggressive behaviour on the part of males" (Herman 1984, 52). ${ }^{4}$ Under the influence of rape culture, some people believe that sexual violence is an inevitable facet of everyday life. They subconsciously excuse perpetrators of sexual violence, and hence they are uninterested in understanding sexual violence and its effects (Mendes 2015, 6; O’Neal 2017, 129; Powell and Henry 2014, 2). The responsibilities of sexual violence are commonly switched from perpetrators to victims as if the latter were accountable for their sufferings because of their appearances and the way they dress (Baum, Cohen, and Zhukov 2018, 271; Keller, Mendes, and Ringrose 2018, 23-24). Furthermore, some people perceive that certain women, such as sex workers and women of colour, cannot be sexually assaulted. The credibility of these victims is often questioned (Mendes 2015, 6; O'Neal 2017, 145-146). Therefore, it is predictable that sexual violence is common in societies where rape culture is prevalent, yet the reporting rates are low (Baum, Cohen, and Zhukov 2018, 265; Mendes 2015, 8).

\section{THE \#METOO MOVEMENT IN HONG KonG}

Although Hong Kong is considered to be a part of China, rape culture in the city is not that prevalent, because its government, non-governmental organizations, and education sector view sexual violence as an intolerable offence and deal with it seriously. For example, an hour after Vera Lui's post, Watsons Athletic Club, of which Lui is a prominent member, suspended the suspected coach from duty (Watsons Athletic Club 2017). This prompted the Chief Executive of Hong Kong, Carrie Lam, to order the then-Commissioner of Police, Stephen Lo, to follow the case. Subsequently, the police went to Lui's previous secondary school to investigate the incident, even though Lui had not officially reported the case to the police. Lam, on the other hand, encouraged other victims of sexual misconduct to seek help (Su and Leung 2017). Moreover, Hong Kong is not under the constraints of the "Great Firewall of China". Hong Kong netizens can access Facebook and Twitter without using virtual private networks. Due to the online disinhibition effect (Suler 2004), victims of sexual assault are more willing to disclose their experiences, which are generally avoided in the offline settings in Hong Kong, via social media (Erni 2017, 33-34; Leung 2017, 934; Zhang et al. 2019, 201-202). Therefore, it is widely expected that more victims of sexual assault would participate in the \#MeToo Movement in Hong Kong.

\footnotetext{
3 "WoYeShi" is the pinyin for the Chinese counterpart of "me too".

${ }^{4}$ In this article, I extend the scope of rape culture to address all types of sexual violence.
} 
One day after Lui's post, a columnist, Chip Tsao, who is better known by his pen name "Kit To", published a post titled "Brothers and sisters, let's speak out" on his Facebook page:

During my kindergarten study, a female teacher touched my face. I now think that I was a victim of sexual assault at that time [...] There are rapists everywhere in Hollywood, and the sports world of Hong Kong is so dirty. Are there any perpetrators among academics and the clergy? Is it possible that our entertainment world is such an ideal place for everyone to strive for artistic excellence? [My translation]

Tsao is keen on political satire. He did not include the \#MeToo hashtag in his post, and he exaggerated his childhood experience as a sexual assault. Hence, his post should not be considered as an ordinary \#MeToo post, but an appeal to victims of sexual assault in all walks of life to speak out.

As a member of the entertainment community of Hong Kong, Louisa Mak published her \#MeToo post two days after Tsao's appeal. However, since the Facebook posts of Lui and Mak, no other Hong Kong celebrities have used social media to share any experience of being sexually assaulted. This raises two possible scenarios: is it likely that Hong Kong provides a safe environment that is free from sexual misconduct? Or are there factors within the Hong Kong society, such as the prevalence of rape culture, that inhibit the \#MeToo Movement from progressing?

\section{METHODS}

In order to address these questions, I analysed the comments on Lui and Mak's Facebook posts, as there were no other associated sources of reliable information available. There were many comments to analyse, which kept increasing while the study was ongoing. To analyse these comments, I used content analysis, a widely used method in media and communication studies, which is recognised for its ability to handle large amounts of data (Deacon et al. 2010, 119; Krippendorff 2013, 17). Instead of counting the frequencies of the manifested content, I chose to focus on the qualitative aspects, in order to understand the characteristics of the content (George 1959, 9-10; Holsti 1969, 10; Krippendorff 2013, 89).

In both Facebook posts, I enabled the "all comments" function so that all comments on the posts were displayed. I copied all "original comments" on each post into a Microsoft Word document and discarded the "follow-up comments". 5 The copied comments were arranged in the order of their posting time, and the first 500 comments on each of the posts were selected as the data set. I read the selected comments and highlighted their keywords. Keywords with similar thematic content were grouped together to form a coding sheet. Regardless of the previous highlighting, I conducted the coding on the selected comments. Based on the codes, I categorized the comments into different types. I referred to Jansen et al. (2009), who studied Twitter accounts of commercial brands, to form the basis of my list of categories. I removed those categories that were related to commercial activities, such as announcing a product, expecting a product, and ordering via Twitter. Then, I added some categories which were relevant to user comments from Madden, Ruthven, and McMenemy (2012), such as agreement, anecdote, and insult. In addition, I created a new category of "ideological comment", collecting comments that mentioned China and its subordinates. Table 1 below shows the types of comments and their descriptions:

\footnotetext{
${ }^{5}$ I refer to "original comments" as those comments that directly responded to the posts, while "follow-up comments" were those responding to comments.
} 
Table 1 Types of comments and their descriptions

\begin{tabular}{ll}
\hline Type of comment & Description \\
\hline Agreement & Expressing agreement with something in the original post \\
Anecdote & Telling a story about the commenter's personal experience \\
Comparison & Comparing the original post to another \\
Ideological comment & Referring to China or pro-establishment organizations \\
Insult & Attacking, insulting the original poster \\
Negative comment & Expressing negative sentiments (not towards the original poster) \\
Notification & Suggesting to others to read the original post \\
Positive comment & Complimenting, praising, greeting \\
Question & Expressing confusions or doubts \\
Recommendation & Providing advice \\
Request & Asking the original poster to provide more details \\
Supplement & Providing supplementary information to the original post \\
\hline
\end{tabular}

Qualitative content analysis can clearly show the difference between the frequencies of different types of comments on the two Facebook posts, but it is incapable of analysing the commenters' reasons for making such comments. To address this, I also employed critical discourse analysis, a popular method in media and communication studies (Blommaert and Bulcaen 2000, 451; Deacon et al. 2010, 150-151). In this paper, I used van Dijk's (2008, 91-93) approach to the method, in which the relationships between discourses and society are analysed through cognition. I studied the comments on Mak's post which I categorised as "comparisons", "insults", "negative comments", and "questions". Through closely reading these four types of comments, I assessed which perspectives the commenters took and what beliefs about society the commenters held.

\section{RESULTS}

The composition of the comments to the \#MeToo posts of Vera Lui and Louisa Mak is as follows in Table 2:

Table 2 Composition of the comments

\begin{tabular}{lcc}
\hline Type of comment & Lui's post & Mak's post \\
\hline Agreement & $0.2 \%$ & $3.8 \%$ \\
Anecdote & $0 \%$ & $0.6 \%$ \\
Comparison & $0 \%$ & $4.6 \%$ \\
Ideological comment & $0.2 \%$ & $3.2 \%$ \\
Insult & $0.2 \%$ & $18.6 \%$ \\
Negative comment & $5.0 \%$ & $6.8 \%$ \\
Notification & $0 \%$ & $8.0 \%$ \\
Positive comment & $90.6 \%$ & $32.2 \%$ \\
Question & $0.4 \%$ & $6.0 \%$ \\
Recommendation & $3.0 \%$ & $7.0 \%$ \\
Request & $0 \%$ & $1.4 \%$ \\
Supplement & $0 \%$ & $5.0 \%$ \\
Unclassifiable comment & $0.4 \%$ & $2.8 \%$ \\
\hline
\end{tabular}


Lui was the first Hong Kong celebrity who revealed her experience of being sexually assaulted. She explained the nature of the relationship she had with her coach before the incident, described the abusive incident in detail, and, notably, chose to post her message on her birthday. It is understandable that she received many supportive comments, praise for her bravery, and birthday greetings. Some commenters despised Lui's coach for his wrongdoing, especially given that Lui was only a child when she was sexually assaulted. As a result, a number of comments condemned the coach. Lui had refused to report her case to the police; this propelled some commenters to advise her to do so for her own safety. However, it is remarkable that one commenter criticized Lui for not reporting her coach immediately after the incident, giving her coach the opportunity to sexually assault other trainees. This is an alternative type of victim-blaming (Boyle 2019, 84-88; Mendes 2015, 91-93; Whiting et al. 2019, 80), as if Lui were responsible for other cases of sexual assault that happened in the sports community.

In comparison, Mak did not disclose the details of the incident, but she explained how the trial process helps to safeguard the opportunities for victims to be heard, and she demonstrated to the public that she was resolute in avoiding any further sexual assaults. This determination and her knowledge of the law earned compliments and recognition from the netizens, but she received far fewer positive comments than did Lui. At the same time, some commenters asked Mak to clarify the definitions of a number of complicated legal terms, whereas some netizens interpreted the legal terms themselves and discussed the differences between different legal systems. Some commenters even invited their friends to engage in the discussions. One of the discussion topics was about whether the courts of law in Hong Kong have jurisdiction over criminal cases that happen in mainland China. This topic arose because Mak had not taken further legal actions against the perpetrators since she had been sexually assaulted in mainland China. As a result, some pro-democracy netizens commented on the decadence of morals among the Mainlanders, and some commenters recommended that Mak report the cases, as she did not mention whether she had informed the police. But surprisingly, many netizens neither supported nor sympathized with Mak (Mendes, Ringrose, and Keller 2018, 238), but caused secondary victimization to the victim by disbelieving or even blaming her (Laing 2017, 1316; Mendes 2015, 7-9; Patterson 2011, 329). Through critical discourse analysis, I studied the comments that I classified as "comparisons", "insults", "negative comments", and "questions", and categorized them into six themes, which I will discuss in the following sections.

\section{1. "You'd better be careful when you go abroad, you know you are so beautiful"'}

As mentioned above, among the first 500 comments received by Lui, there was one victim-blaming comment. Surprisingly, Mak received considerably more victim-blaming comments than did Lui. In her post, Mak noted that she had been sexually assaulted more than once - some of the incidents were unavoidable, while she could have avoided the others if she had been more alert to the intentions of the perpetrators. However, some commenters blamed the victim by simply imputing the tragedies to Mak's inattentiveness (Whiting et al. 2019, 80), and others believed in rape myths -misconceptions about sexual violence derived from rape culture - giving their attention to the number of sexual assaults Mak confronted (Kunst et al. 2019, 821; Mendes 2015, 30; O’Neal 2017, 129).

\footnotetext{
${ }^{6}$ The headings of these six sections were extracted and translated from the comments on Mak's post.
} 
They thought that she was totally against the first assault, but she might have been less unwilling during the subsequent incidents, or even enjoyed them.

Another reason underpinning the prejudice against Mak was that she studied in England between 2009 and 2014 (Lai 2015). Some netizens presumed that women in the West were more open-minded than Asian women. They thought that female Asian students studying abroad would wear sexy clothing to better assimilate into Western communities (Yin et al. 2019, 410-411). Some comments on Mak's post were photos in which she showed her cleavage. The commenters urged her to ensure that she did not appear overly sexual, to avoid attracting perpetrators. Some argued that her sexy appearance made her more vulnerable to sexual assault and urged her not to travel to any place which fell outside the Hong Kong courts' jurisdiction, otherwise the perpetrators would easily evade retribution. These comments constituted slut-shaming, which is a manifestation of rape culture. Similar to victim-blaming, the action of slut-shaming switches the responsibilities of sexual assault from the perpetrators to the victims (Baum, Cohen, and Zhukov 2018, 271; Keller, Mendes, and Ringrose 2018, 23-24; Mendes 2015, 92-93).

\section{2. "At least you have not taken photos with the perpetrators after the incidents"}

In her post, Mak explained that the complicated criminal procedure and the embarrassment caused by making a statement would discourage victims of sexual assault, including Lui, from reporting their cases to the police. Instead, they took part in the \#MeToo Movement and empowered themselves by telling their experiences to their friends. However, some people, especially men, disapprove of the movement. They are concerned by the potential abuses of the \#MeToo hashtag and by the possibility of being falsely accused of sexual assault (Boyle 2019, 60-61; Starkey et al. 2019, 455). For example, the United States President, Donald Trump, said that the \#MeToo era was "a very scary time for young men in America, when you can be guilty of something that you may not be guilty of' (Bump 2018). Inevitably, some netizens questioned Lui's reasons for not reporting her case to the police. In their comments on Mak's post, some commenters thought that Lui appreciated her coach for his instruction over the years, so she was not hard-hearted enough to prosecute him; in addition, some others found photos taken years after the incident in which Lui and her coach posed happily, noting that Lui refused to report the case because those photos would harm the credibility of her statement.

Mak further suggested that victims of sexual assault reserve evidence by questioning the perpetrators through text messages. For example, Lui could have asked her coach for his reason for taking off her jeans and underpants. Some netizens argued that it was impossible for the coach to take off Lui's underpants without her consent. A few commenters even thought that Lui was fond of her coach, so she did not resist when he took off her underpants. In a word, through commenting on Mak's post, some people questioned the authenticity of Lui's experience of sexual assault, as well as Mak's interpretation of Lui's case. These comments reflected that some people neither supported nor understood the \#MeToo Movement. They also endorsed rape culture, refusing to show empathy for the victims and questioning the victims' credibility (Baum, Cohen, and Zhukov 2018, 271). 


\section{3. "I think what you have experienced falls into the category of sexual harassment"}

Mak used the term sexual assault in her post because she completed a law degree in England (Danby 2016), where sexual assault is defined as intentional, non-consensual contact with another person of the opposite sex. ${ }^{7}$ However, many netizens did not know that this term was identical to indecent assault in the Criminal Law of Hong Kong. ${ }^{8}$ Quite a number of commenters asked Mak about the differences between sexual assault, indecent assault, sexual harassment, and rape. A couple of commenters mistakenly believed that sexual assault must involve genital contact, some believed that Mak had only experienced sexual harassment, and one asked Mak whether she had been raped. These commenters not only discounted the severity of some types of sexual misconduct but also caused Mak to experience secondary victimization. Their questions were similar to those asked by a policeman or a defence counsel, causing Mak to recall the incidents and making her feel embarrassed (Correia et al. 2010, 165; Mendonça, Gouveia-Pereira, and Miranda 2016, 83). In addition, all these interrogating questions from non-professional netizens contribute to reinforce rape culture, which inhibits victims of sexual violence from revealing their experiences (O’Neal 2017, 131-133).

\section{4. "Actresses are prostitutes"}

After winning the Miss Hong Kong pageant in 2015, Mak became a contract actress at Television Broadcasts Limited, the dominant television station in Hong Kong (Kwok 2016). However, many citizens presume that sexual misconduct is rife in the entertainment world. For one thing, it is rumoured that some businessmen pay actresses great sums of money in exchange for sexual intimacy. For example, Joseph Lau, a businessman known for his generosity towards his girlfriends, had a long-term extramarital affair with a former Miss Hong Kong, Michelle Reis, and he named a shopping mall in honour of her even after they had broken up (Kwok 2015). A couple of commenters hence referred to Mak's company as a brothel and its actresses as prostitutes. Under the rape myth that prostitutes cannot be sexually assaulted (Baum, Cohen, and Zhukov 2018, 271; Mendes 2015, 6), it is predictable that these commenters disbelieved Mak's incidents. They sarcastically asked Mak not to attend millionaires' parties to avoid being sexually assaulted. These prejudices against actresses imply that they are objectified (Nussbaum 2011, 69-70). The commenters held actresses in contempt and perceived them as businessmen's playmates.

On the other hand, some actors at the television station have been accused of sexual assault by their colleagues. In November 2011, for example, Rose Chan held a press conference, alleging that she had been sexually assaulted by Benny Chan and Joe Ma in China during a meal after filming (Hui, Toh, and Raman 2011). Coincidentally, Mak was sexually assaulted in China. A commenter mentioned Chan's incident and asked Mak which supervisors or actors were the perpetrators of her case as if for every actress who was sexually assaulted in China, the perpetrator could only be her colleague.

\footnotetext{
${ }^{7}$ Sexual Offences Act 2003, 42 UK Public General Acts $§ 3$ (2003), http://www.legislation.gov.uk/ukpga/2003/42/section/3.

${ }^{8}$ Crimes Ordinance, 200 Hong Kong Ordinances $\$ 122$ (2017),

https://www.elegislation.gov.hk/hk/cap200?xpid=ID_1438402823378_003.
} 


\section{5. "It's time for some newsjacking"9}

In Chan's above-mentioned case, one of the accused, Joe Ma, subsequently proved himself innocent (Hui, Toh, and Raman 2011). As a result, Chan was condemned for falsely accusing Ma. Similarly, a few commenters noted that the tone of Mak's post was too calm. They did not believe her post, as if she had newsjacked the \#MeToo Movement by fabricating a story to generate publicity for herself.

This preconceived image of Mak was formed because she frequently commented on current affairs on her Facebook page. During the Rio Olympics, for example, she was stationed in Rio de Janeiro as a member of the live commentary team for her company. A radio host, Suzie Wong, criticized a table tennis player, Chun-ting Wong, for not buttoning up his polo shirt during matches. Subsequently, Mak newsjacked this incident by wearing an unbuttoned polo shirt to interview Chun-ting. On August 16, 2016, she posted a photo of the interview on Facebook and received over 4,000 likes. However, Mak's \#MeToo post was also viewed as a newsjacking tactic. Some commenters were tired of reading her newsjacking posts, but they could not imagine she would "reveal" her experiences of being sexually assaulted; some others questioned why she had not revealed the case during the beauty pageant, but only after Lui's post; and one commenter criticized Mak for using "sexual assault" to take advantage of "real" victims, such as rape victims. Similar to those comments that discounted the severity of the sexual assault, these comments also brought secondary victimization to Mak.

\section{6. "Support implementation of extrajudicial punishment"}

In the last part of her post, Mak emphasised the importance of self-protection. She began to learn Jujitsu, a Japanese martial art, after experiencing those unfortunate incidents. Some commenters noted that Jujitsu involves close combat, which may hinder a victim from escaping the perpetrator. They recommended Mak learn other forms of martial arts, such as Tae Kwon Do, or Kapap, an Israeli self-defence method. On the other hand, a few commenters did not discuss self-defence, but advocated extrajudicial punishment. One of them even urged Mak to kick the perpetrators' genitals without the slightest hesitation. However, these advocating comments violated Mak's idea of seeking legal retribution against perpetrators.

\section{ONLINE JUDGING}

As shown in the previous section, Mak received quite a number of victim-blaming and slut-shaming comments (Keller 2016, 93; Mendes 2015, 5; Starkey et al. 2019, 447). A notable example is that a commenter kept posting Mak's sexy photos, implying that she was the culprit of her own experiences of sexual assault. These types of comments are deemed to be quite predictable, given the prevalence of rape culture in both online and offline settings (Hildebrand and Najdowski 2015, 1062-1066; Kunst et al. 2019, 821; Mendes, Ringrose, and Keller 2018, 242-243). On the other hand, some unsympathetic commenters, who attempted to distance themselves from the sensitive topic of sexual

\footnotetext{
${ }^{9}$ Newsjacking is a term coined by combining "news" and "hijacking”, meaning a process of adding one's ideas and opinions to a piece of breaking news in order to receive more media coverage (Adi 2015, 513).
} 
violence, also brought secondary victimization to Mak (Gekoski 2013, 308; Leung 2017, 936; Mendonça, Gouveia-Pereira, and Miranda 2016, 83). Without emotional support from their relatives and friends, some victims of sexual assault have to face the fear and shame on their own when they report the cases. Therefore, many victims refuse to disclose their cases (Laing 2017, 1316; Patterson 2011, 336-339). This is harmful to societies, in that perpetrators are "allowed and encouraged" to engage in further sexual assaults (Hildebrand and Najdowski 2015, 1062; Orth 2002, 323).

One of Alyssa Milano's purposes of introducing the \#MeToo Movement was to guard against further cases of sexual assault and harassment through speaking up. Although some argue that the movement overemphasizes the breaking of silence and overlooks the importance of justice (Kay 2020, 36-39), victims of sexual misconduct are indeed empowered through empathy. However, the development of the movement in Hong Kong and China was quite different from that in other countries. While the Chinese authorities banned their netizens from reading and publishing \#MeToo posts, netizens in Hong Kong can participate in the movement freely. Nevertheless, as the second celebrity who published a \#MeToo post in Hong Kong, Mak received quite a lot of comments that endorsed rape culture — engaging in victim-blaming and slut-shaming, discounting the severity of the sexual assault, and condemning her for creating fake stories (Baum, Cohen, and Zhukov 2018, 271; Mendes 2015, 5-6; Powell and Henry 2014, 2) - as well as comments that attempted to persuade Mak to inflict extrajudicial punishments on the perpetrators. Viewing these comments as a whole, they can be imagined as a kind of criminal procedure: ${ }^{10}$ there were "detectives" searching for photos of Lui and Mak as "evidence"; "counsels" interrogating Mak about whether she had been raped and who the perpetrators were; a "jury" finding Mak guilty of perjury; and "judges" sentencing the perpetrators to physical punishments. I refer to this form of commenting as "online judging" - a form of trial process conducted over the Internet. In contrast to a court trial, such a process does not require a predetermined date for a case hearing, and "benefited" by the characteristics of the Internet, a case can be "tried" in a short time (Kim 2017, 806; Mantilla 2013, 564). Further, the process is not presided over by a judge, but any netizen around the world, and has no input from a jury in reaching a verdict. We can well imagine that the judgments made are not necessarily supported by evidence, but driven by personal emotions and opinions.

As a result, online judgments often consist of personal attacks. For example, one commenter condemned Mak as a "bitch" who newsjacked the \#MeToo Movement. Nevertheless, those online judges seemingly perceive themselves as envoys of justice. This is probably because they believed that the \#MeToo Movement was unable to deliver justice, and they have been disappointed in law enforcers - the Hong Kong Police - since the Umbrella Movement. ${ }^{11}$ For example, on September 28, 2014, when confronted with unarmed peaceful protesters, the police fired 87 shots of tear gas canisters in an attempt to disperse the crowd (Hui 2017, 148). On a subsequent occasion, when those pro-democracy protesters were attacked by a pro-establishment mob, the police refrained from containing the mob, and some officers even cheered the mob on. Many pro-democracy residents believe that the police are selectively enforcing the law by only serving the authorities and not the general public (Lo et

\footnotetext{
${ }^{10}$ Criminal Procedure Ordinance, 221 Hong Kong Ordinances $\S 1$ et seq. (2018). https://www.elegislation.gov. $\mathrm{hk} / \mathrm{hk} / \mathrm{cap} 221$ !en?INDEX_CS=N

${ }^{11}$ The Umbrella Movement was a massive demonstration for universal suffrage which took place in Hong Kong in 2014. A number of business districts were occupied by protesters for more than 70 days (Flowerdew 2017; Tong 2017).
} 
al. 2019, 528-529). A notable example of the incongruous manner of operation on the part of the police that related to online activities occurred when Chai-yan Leung, the daughter of Chun-ying Leung, the then-Chief Executive, put a post on her Facebook page accusing her mother of abusing her. The then-Commissioner of Police, Andy Tsang, refused to respond and stated that the police has no obligation to investigate every criminal case posted on the Internet (Fung 2015). When it came to Lui's case, however, the police investigated the incident even though no one had formally reported it to them. By accusing the victims of perjury, the netizens ridiculed the police's "false investigations" as a way of challenging the authorities.

Although some argue that bringing perpetrators to court trials may not necessarily deliver justice (Pellegrini 2018, 263), conducting online judging certainly fails to restore justice and causes secondary victimization of the victims. In this regard, the actions of the netizens also hindered the \#MeToo Movement in Hong Kong. On December 20, 2017, Mak posted on her Facebook page about the undue additional stress the victim-blaming comments caused her. In order to encourage other victims to withstand the pressure of online judging, she disregarded the risk of being judged online even further and provided evidence and clarifications in response to the derogatory comments she had received from commenters. This follow-up post was proof of the destructive power of online judging. Unfortunately, the pressure of online judging is so high that after Mak, no other Hong Kong celebrities demonstrated sufficient resolve to reveal their own \#MeToo experiences on social media. Moreover, Mak was not the only casualty of online judging. As the netizens gathered increasing "evidence", Lui, inevitably, also became their target. Ultimately, the \#MeToo Movement in Hong Kong ended in failure, as the number of participants was far too low to create a sense of empowerment for the victims.

\section{CONCLUSION}

At the time when the \#MeToo Movement was gaining momentum worldwide, two Hong Kong celebrities, Vera Lui and Louisa Mak posted their personal experiences on their Facebook pages. Until the time of this study, however, a third celebrity has not yet appeared. In order to investigate the factors that hindered the movement from developing in Hong Kong, I studied the first 500 comments on the \#MeToo posts of Lui and Mak. Lui received over 450 positive comments, whereas only about 150 comments received by Mak were positive in nature, and the latter received even more comments that endorsed rape culture and inflicted secondary victimization on her. Among these victimizing comments, apart from traditional victim-blaming and slut-shaming, commenters acted as online judges to accuse Mak of newsjacking the \#MeToo Movement, whereas some of them convinced her to impose extrajudicial punishments on the perpetrators. The commenters believed that the Hong Kong Police enforced the law selectively, and therefore they negated the victims' stories in order to challenge the authorities. These actions did not help in restoring justice but hindered other celebrities from revealing any personal experiences related to the \#MeToo Movement. As a result, the \#MeToo Movement in Hong Kong failed to develop as fully as in other parts of the world.

The failure of the \#MeToo Movement in Hong Kong, however, did not bring online judging to a halt. On the contrary, following the deterioration of public satisfaction with the police over the 2019 protests against the Fugitive Offenders Amendment Bill (Purbrick 
2019, 477), online judging has become quite a usual practice among netizens, especially when they "investigated" cases of an apparent suicide that were not considered suspicious by the police. For example, the naked corpse of a 15-year-old girl, Christy Chan, was found in the sea on September 22, 2019 (Chan 2019). Though the police confirmed this case as an unsuspicious suicide, netizens found some records of Chan winning medals in swimming competitions, and deemed that it was impossible for a competent swimmer to drown herself. Protesters hence demanded that Chan's school, the Hong Kong Design Institute, provide the CCTV footage taken before her death (Lew 2019). Then, they observed that the footage had been edited. They suspected that the school and the police were colluding to conceal the truth about Chan's death.

On the other hand, the aggravation of the selective law enforcement on the part of the police has caused protesters to implement extrajudicial punishments to protect themselves. It was found on numerous occasions that the police had harboured armed pro-establishment rioters who attacked peaceful protesters. On July 21, 2019, for example, a mob beat protesters and innocent passengers with rattans in the Yuen Long Railway Station. However, the police waited until the mob had left and arrived at the station about 40 minutes after the case was reported (Lee et al. 2019, 10-11; Purbrick 2019, 473). Learning from these experiences, some protesters would not report to the police if they are under attack but would gather other protesters to counterattack (Ting 2020,366). As the protests continue in 2020, similar cases of online judging and extrajudicial punishment are expected to keep emerging.

Online judging is not a problem unique to Hong Kong. In addition to giving mutual support to victims of sexual assault through empathy, the \#MeToo Movement in itself also provides opportunities for the general public to comment on suspects of sexual assault through social media. In other words, before having a chance to defend themselves in a court trial, the suspects are already under some sort of "trial" (Zarkov and Davis 2018, 6). Moreover, comments similar to those received by Mak can be found all around the world. For example, American actor, Matt Damon, stated that sexual misconduct consisted of "a spectrum of behaviour" (Valiente and Williams 2017), implying that some forms of sexual misconduct need not be confronted as seriously as others. Speeches similar to this have not only reinforced the prevalence of rape culture and result in secondary victimization of victims, but have also caused backlashes against the \#MeToo Movement (Boyle 2019, 60-66). In this regard, scholars could go into further detail by studying how rape culture and online judging affect the \#MeToo Movement in different places, and what issues online judging brings to different societies.

\section{REFERENCES}

Adi, Ana. "Occupy PR: An Analysis of Online Media Communications of Occupy Wall Street and Occupy London". Public Relations Review 41 (2015): 508-514

Baum, Matthew A., Dara Kay Cohen, and Yuri M. Zhukov. "Does Rape Culture Predict Rape? Evidence from U.S. Newspapers, 2000-2013”. Quarterly Journal of Political Science 13 (2018): 263-289.

Blommaert, Jan, and Chris Bulcaen. "Critical Discourse Analysis". Annual Review of Anthropology 29 (2000): 447-466.

Boyle, Karen. \#MeToo, Weinstein and Feminism. Cham: Palgrave Macmillan, 2019.

Bump, Philip. "Trump Says It's 'a Very Scary Time' for Young Men - but That Women Are 'Doing Great"'. The Washington Post, October 2, 2018. Available at: https://www.washingtonpost.com/politics/2018/10/02/trumpsays-its-very-scary-time-young-men-that-women-are-doing-great. 
Chan, Ho-him. "Mother of 15-year-old Hong Kong Girl Found Dead in Sea Says Daughter Took Her Own Life, and Calls for End to Harassment of Family and Speculation over Death." South China Morning Post, October 17, 2019. Available at: https://www.scmp.com/news/hong-kong/politics/article/3033448/mother15-year-old-hong-kong-girl-found-dead-sea-says.

Chen, Christie, Shih-yi Liu, and Sabine Cheng. "Promising Writer Dies at 26 from Apparent Suicide". Focus Taiwan, April 28, 2017. Available at: https://focustaiwan.tw/society/201704280011.

Correia, Isabel, Hélder Alves, Ana Tomás De Almeida, and D’Jamila Garcia. "Norms Regarding Secondary Victimization of Bullying Victims: Do They Differ According to the Victim's Categorization?" Scandinavian Journal of Psychology 51 (2010): 164-170.

Danby, Poppy. "Miss Hong Kong Is Thrown out of a Cambridge University Party after Workers Thought She Was an Impostor 'Because Her Teeth Weren't Good Enough"'. Daily Mail, March 7, 2016. Available at: https://www.dailymail.co.uk/news/article-3480316.

Deacon, David, Michael Pickering, Peter Golding, and Graham Murdock. Researching Communications: A Practical Guide to Methods in Media and Cultural Analysis, 2nd ed. London: Hodder Arnold, 2010.

Denyer, Simon, and Amber Ziye Wang. "Chinese Women Reveal Sexual Harassment, but \#MeToo Movement Struggles for Air". The Washington Post, January 9, 2018. Available at: https://www.washingtonpost.com/ world/asia_pacific/chinese-women-reveal-sexual-harassment-but-metoo-movement-struggles-for-air/2018/ 01/08/ac591c26-cc0d-4d5a-b2ca-d14a7f763fe0_story.html.

Erni, John Nguyet. "Sex and Freedom in the Chatroom: The Hong Kong Golden Forum as Method". In Hong Kong Culture and Society in the New Millennium: Hong Kong as Method, edited by Yiu-Wai Chu, 33-58. Singapore: Springer Nature, 2017.

Fadnis, Deepa. "Uncovering Rape Culture: Patriarchal Values Guide Indian Media's Rape-related Reporting". Journalism Studies 19 (2018): 1750-1766.

Flowerdew, John. "Understanding the Hong Kong Umbrella Movement: A Critical Discourse Historiographical Approach". Discourse \& Society 28 (2017): 453-472.

Fung, Fanny W. Y. "Police Chief Defends Move Not to Pursue CY Leung Daughter's Claim of Violence at Home". South China Morning Post, March 22, 2015. Available at: https:/www.scmp.com/news/hongkong/article/1744088/police-chief-defends-move-not-pursue-cy-leung-daughters-claim.

Gekoski, Anna, Joanna R. Adler, and Jacqueline M. Gray. "Interviewing Women Bereaved by Homicide: Reports of Secondary Victimization by the Criminal Justice System". International Review of Victimology 19 (2013): 307-329.

Gentile, Jill. The P*ssy Missile Has Launched: Free Speech Effects of the Women's March as Prelude to \#MeToo, and with a Coda". Studies in Gender and Sexuality 19 (2018): 256-261.

George, Alexander L. "Quantitative and Qualitative Approaches to Content Analysis". In Trends in Content Analysis, edited by Ithiel de Sola Pool, 7-32. Urbana: University of Illinois Press, 1959.

Gill, Rosalind, and Shani Orgad. "The Shifting Terrain of Sex and Power: From the 'Sexualization of Culture' to \#MeToo". Sexualities 21 (2018): 1313-1324.

Hassan, Sava. "Weinstein Case Demonstrates Cultural Differences". China Daily, October 16, 2017. Available at: http://www.chinadaily.com.cn/a/201710/16/WS5a0c0771a31061a7384064ea.html.

Healy, Shawn. "The Great Firewall of China”. Social Education 71 (2007): 158-163.

Herman, Dianne F. "The Rape Culture.” In Women: A Feminist Perspective, 3rd ed., edited by Jo Freeman, 4553. Mountain View: Mayfield, 1984.

Hernández, Javier C., and Zoe Mou. "“Me Too,' Chinese Say. Not So Fast, Say the Censors”. The New York Times, January 24, 2018.

Hildebrand, Meagen H., and Cynthia J. Najdowski. "The Potential Impact of Rape Culture on Juror Decision Making: Implications for Wrongful Acquittals in Sexual Assault Trials". Albany Law Review 78 (2015): 1059-1086.

Holsti, Ole R. Content Analysis for the Social Sciences and Humanities. London: Addison-Wesley, 1969.

Hui, Beh Yuen, Terence Toh, and A. Raman. HK Actor Apologises for Molesting Rose Chan”. The Star, December 17, 2011. Available at: https://www.thestar.com.my/news/nation/2011/12/17/hk-actor-apologises-for-molestingrose-chan.

Hui, Yew-Foong. "The Umbrella Movement: Ethnographic Explorations of Communal Re-spatialization". International Journal of Cultural Studies 20 (2017): 146-161.

Jansen, Bernard J., Mimi Zhang, Kate Sobel, and Abdur Chowdury. "Twitter Power: Tweets as Electronic Word of Mouth". Journal of the American Society for Information Science and Technology 60 (2009): 2169-2188.

Kay, Jilly Boyce. Gender, Media and Voice: Communicative Injustice and Public Speech. Cham: Palgrave Macmillan, 2020. 
Keller, Jessalynn. "'Loud, Proud, and Sarcastic': Young Feminist Internet Communities as Networked Counterpublics". In Girls' Feminist Blogging in a Postfeminist Age, edited by Jessalynn Keller, 76-113. New York: Routledge, 2016.

Keller, Jessalynn, Kaitlynn Mendes, and Jessica Ringrose. 'Speaking 'Unspeakable Things:' Documenting Digital Feminist Responses to Rape Culture". Journal of Gender Studies 27 (2018): 22-36.

Kim, Jinsook. "\#iamafeminist as the "Mother Tag": Feminist Identification and Activism against Misogyny on Twitter in South Korea". Feminist Media Studies 17 (2017): 804-820.

Krippendorff, Klaus. Content Analysis: An Introduction to Its Methodology. 3rd ed. Thousand Oaks: SAGE Publications, 2013

Kunst, Jonas R., April Bailey, Claire Prendergast, and Aleksander Gundersen. "Sexism, Rape Myths and Feminist Identification Explain Gender Differences in Attitudes toward the \#metoo Social Media Campaign in Two Countries". Media Psychology 22 (2019): 818-843.

Kwok, Ben. "Joseph Lau and the Gift That Keeps on Giving”. Hong Kong Economic Journal, November 12 , 2015. Available at: http://www.ejinsight.com/20151112-joseph-lau-the-gift-that-keeps-on-giving.

Kwok, Ben. "Can Louisa Mak Win It Again”. Hong Kong Economic Journal, January 19, 2016. Available at: http://www.ejinsight.com/20160119-can-louisa-mak-win-it-again.

Lai, Ying-kit. "My Biggest Setback: Miss Hong Kong Louisa Mak Says Failure to Win UK Scholarship Was a 'Lesson in Life"'. South China Morning Post, September 1, 2015. Available at: https://www.scmp.com/news/ hong-kong/education-community/article/1854334/my-biggest-setback-miss-hong-kong-louisa-mak-says.

Laing, Lesley. "Secondary Victimization: Domestic Violence Survivors Navigating the Family Law System". Violence Against Women 23 (2017): 1314-1335.

Lee, Francis L. F., Samson Yuen, Gary Tang, and Edmund W. Cheng. "Hong Kong's Summer of Uprising: From Anti-Extradition to Anti-authoritarian Protests". The China Review 19 (2019): 1-32.

Leung, Lai Ching. "Understanding the Help-Seeking Decisions of Sexual Assault Survivors: Implications for Social Work Practice in Hong Kong”. International Social Work 60 (2017): 927-940.

Lew, Linda. "Classes Suspended at Hong Kong Design Institute after Students Vandalise Campus Demanding Surveillance Footage of Classmate Found Dead in Sea". South China Morning Post, October 15, 2019. Available at: https://www.scmp.com/news/hong-kong/politics/article/3032907/classes-suspended-hong-kongdesign-institute-after-students.

Lo, T. Wing, Cora Y. T. Hui, Sharon Ingrid Kwok, and Gabriel K. W. Lee. "Tolerance of Triads, Police Legitimacy, and Self-help amidst the Umbrella Movement". Australian \& New Zeland Journal of Criminology 52 (2019): 516-533.

Madden, Amy, Ian Ruthven, and David McMenemy. "A Classification Scheme for Content Analyses of YouTube Video Comments". Journal of Documentation 69 (2012): 693-714.

Mantilla, Karla. "Gendertrolling: Misogyny Adapts to New Media”. Feminist Studies 39 (2013): 563-570.

Mendes, Kaitlynn. Slutwalk: Feminism, Activism and Media. Basingstoke: Palgrave Macmillan, 2015.

Mendes, Kaitlynn, Jessica Ringrose, and Jessalynn Keller. "\#MeToo and the Promise and Pitfalls of Challenging Rape Culture through Digital Feminist Activism”. European Journal of Women's Studies 25 (2018): 236-246.

Mendonça, Rita Duarte, Maria Gouveia-Pereira, and Mariana Miranda. "Belief in a Just World and Secondary Victimization: The Role of Adolescent Deviant Behavior". Personality and Individual Differences 97 (2016): 82-87.

Nussbaum, Martha C. "Objectification and Internet Misogyny”. In The Offensive Internet: Speech, Privacy, and Reputation, edited by Saul Levmore, and Martha C. Nussbaum, 68-87. Cambridge: Harvard University Press, 2011.

Ohlheiser, Abby. "The Woman behind 'Me Too' Knew the Power of the Phrase When She Created It - 10 Years Ago". The Washington Post, October 19, 2017. Available at: https://www.washingtonpost.com/ news/the-intersect/wp/2017/10/19/the-woman-behind-me-too-knew-the-power-of-the-phrase-when-shecreated-it-10-years-ago.

O'Neal, Eryn Nicole. "'Victim is Not Credible': The Influence of Rape Culture on Police Perceptions of Sexual Complainants". Justice Quarterly 36 (2019): 127-160.

Orth, Uli. "Secondary Victimization of Crime Victims by Criminal Proceedings". Social Justice Research 15 (2002): 313-325.

Patterson, Debra. "The Linkage between Secondary Victimization by Law Enforcement and Rape Case Outcomes”. Journal of Interpersonal Violence 26 (2011): 328-347.

Pellegrini, Ann. “\#MeToo: Before and after”. Studies in Gender and Sexuality 19 (2018): 262-264.

Powell, Anastasia, and Nicola Henry. "Framing Sexual Violence Prevention: What Does It Mean to Challenge a Rape Culture". In Preventing Sexual Violence: Interdisciplinary Approaches to Overcoming a Rape Culture, edited by Nicola Henry, and Anastasia Powell, 1-21. Basingstoke: Palgrave Macmillan, 2014. 
Purbrick, Martin. “A Report of the 2019 Hong Kong Protests”. Asian Affairs 50 (2019): 465-487.

Rodino-Colocino, Michelle. "Me Too, \#MeToo: Countering Cruelty with Empathy". Communication and Critical/Cultural Studies 15 (2018): 96-100.

Srivastava, D. K., and Min Kang Gu. "Law and Policy Issues on Sexual Harassment in China: Comparative Perspectives". Oregon Review of International Law 11 (2009): 43-69.

Starkey, Jesse C., Amy Koerber, Miglena Sternadori, and Bethany Pitchford. "\#MeToo Goes Global: Media Framing of Silence Breakers in Four National Settings". Journal of Communication Inquiry 43 (2019): 437-461.

Su, Xinqi, and Christy Leung. "Hong Kong Hurdler Vera Lui's Claim That a Coach Sexually Assaulted Her When She Was 13 Sparks Outcry, Police Probe". South China Morning Post, November 30, 2017. Available at: https://www.scmp.com/news/hong-kong/law-crime/article/2122203/coach-sexually-assaultedher-when-she-was-13-hong-kong.

Suler, John. "The Online Disinhibition Effect". CyberPsychology \& Behavior 7 (2004): 321-326.

Ting, Tin-yuet. "From 'Be Water' to 'Be Fire': Nascent Smart Mob and Networked Protests in Hong Kong". Social Movement Studies 19 (2020): 362-368.

Tong, Carmen. "A Chronology of Hong Kong's Umbrella Movement: January 2013-December 2014". Educational Philosophy and Theory 51 (2017): 194-199.

Valiente, Alexa, and Angela Williams. Matt Damon Opens up about Harvey Weinstein, Sexual Harassment and Confidentiality Agreements". ABC News, December 14, 2017. Available at: https://abcnews.go.com/Entertainment/mattdamon-opens-harvey-weinstein-sexual-harassment-confidentiality/story?id=51792548.

Van Dijk, Teun Adrianus. Discourse and Power. Basingstoke: Palgrave Macmillan, 2008.

Watsons Athletic Club. "Watsons Athletic Club Statement". Facebook, November 30, 2017. Available at: https://www.facebook.com/Watsons.Athletic.Club/posts/1495994060455990?_tn_=-R.

Whiting, Jason B., Rachael Dansby Olufowote, Jaclyn D. Cravens-Pickens, and Alyssa Banford Witting. "Online Blaming and Intimate Partner Violence: A Content Analysis of Social Media Comments". The Qualitative Report 24 (2019): 78-94.

Yin, Cheng-Yue, Nan Bi, Patrick Poon, and Yang Sun. "Sexy or Smart? The Impact of Endorser Ethnicity and Portrayal on Chinese Women's Attitudes towards Luxury Advertising". Asia Pacific Journal of Marketing and Logistics 32 (2019): 406-427.

Zarkov, Dubravka, and Kathy Davis. "Ambiguities and Dilemmas around \#MeToo: \#ForHowLong and \#WhereTo". European Journal of Women's Studies 25 (2018): 3-9.

Zhang, Huiping, Yi Zhang, William Wong, Susan Fan, and Paul Siu Fai Yip. "Sexual Coercion among Hong Kong Chinese Adolescents: The Role of Family Factors". Children and Youth Services Review 101 (2019): 201-206.

\section{SUDITI ONLINE SUDIJE: DVA \#METOO SLUČAJA U HONG KONGU}

Tridesetog novembra 2017. godine, atletičarka iz Hong Konga, Vera Lui postavila je fotografiju na Facebook-u označenu s hashtagom \#metoo i opisala svoje iskustvo seksualnoga napada. Tri dana kasnije, glumica Luisa Mak objavila je sličan \#metoo post na svojoj Facebook stranici. Iako su oba posta, posebno onaj od Lui, u prvi mah primili mnogo podržavajućih komentara, s vremenom su komentari postali negativni i usmerili se prema okrivljavanju žrtve. Od kada su se dogodili ovi slučajevi, nijedna druga poznata osoba iz Hong Konga nije rizikovala otkrivanje svojih iskustava $i$ pridružila se \#metoo pokretu. U ovom radu, analizira se prvih 500 komentara postavljenih na oba posta koristeći kvalitativnu analizu sadržaja i kritičku analizu diskursa. Rezultati otkrivaju praksu online suđenja koja sprečava otkrivanje slučajeva seksualnih napada. Rad dodatno opisuje vezu između online suđenja i selektivnog sprovođenja zakona, koji je kontinuirani problem u Hong Kongu.

Ključne reči: \#metoo, Hong Kong, online suđenje, kultura silovanja, sekundarna viktimizacija, selektivno sprovođenje zakona. 